\title{
Christus Victor, Sacerdos et Judex
}

\author{
The Multiple Roles of Christ on Mosan Shrines
}

The Christus Victor or Christus Belliger-Christ trampling the animals of Psalm 90appears on the gable end of three Mosan shrines. ${ }^{1}$ While the psalm evokes four animals being trampled upon by the Lord, these works only show the lion and the dragon, or, alternatively, only the dragon. On one of the gable ends of the Visé shrine, dated 1046, Christ is depicted crushing both animals. This part was inserted into a new shrine in the 1170s (fig. 1). In this composition, the counterpart of the Christus Victor, on the opposite side of the shrine, is a standing Christ crowning St Hadelin and St Remacle. ${ }^{2}$ Both ends of the Amay shrine have also survived, but are currently separated. The nature of the original shrine to which they belonged, however, remains unknown. One short side presents the same symmetric composition as in Visé, but here, instead of Christ, St Ode appears in the centre flanked by the personifications of two virtues. ${ }^{3}$ Finally, the more recent of both shrines of Stavelot, dated around 1250-1260, presents an enthroned figure on each end: Christ with a dragon under his feet on one side and the Madonna and Child on the other (fig. 12-13). ${ }^{4}$

In addition to these three reliquaries, it is necessary to consider the shrine of St Eleutherius in Tournai, dated before the translation of the relics in 1247, as it belongs to the Rheno-Mosan artistic tradition, even if it is not located in the Diocese of Liège, which is the core region of Mosan goldsmiths' art (fig. 9). ${ }^{5}$ The shrine shows the enthroned Christus Victor on one end, while the other end shows the titular saint-St Eleutherius-imitating Christ by crushing a monster. The lost antependium of St Vanne in Verdun, which predates the Visé shrine, should also be added to this iconographic corpus. Although it is not a shrine, it should also be taken into account because of the close cultural ties between the Abbey of St Vanne and the Diocese of Liège. The chronicle of Hugh of Flavigny specifies that on this altar frontal, commissioned by Abbot Richard (1004-1046), the Christus Victor was flanked by St Peter and St Paul. ${ }^{6}$ This passage is of crucial importance, as the iconographic scheme of Christ between two saints was also adopted in the shrine of St Vanne, commissioned by the same Abbot Richard, and the image is found on several other Mosan reliquaries as

\footnotetext{
1 Psalm 90, 13. Psalm 90 of the Vulgate corresponds to Psalm 91 in the modern version of the Bible. The best study of this text and its iconography remains Verdier 1982.

2 Lemeunier/Didier 1988; Balace 2009, 236-237.

3 Verdier 1981; Lemeunier 1989; Stratford 1993, 90-97; Balace 2009, 292-293.

4 Van den Bossche 1989-1990; Van den Bossche 2014.

5 Van den Bossche, 2015.

6 Hugues de Flavigny, Chronicon, II, 374.

Ә Open Access. () 2019 Marcello Angheben, publiziert von De Gruyter. (c) BY-NC-ND Dieses Werk ist lizenziert unter der Creative Commons Attribution-NonCommercial-NoDerivatives 4.0 Lizenz.

https://doi.org/10.1515/9783110629156-005
} 


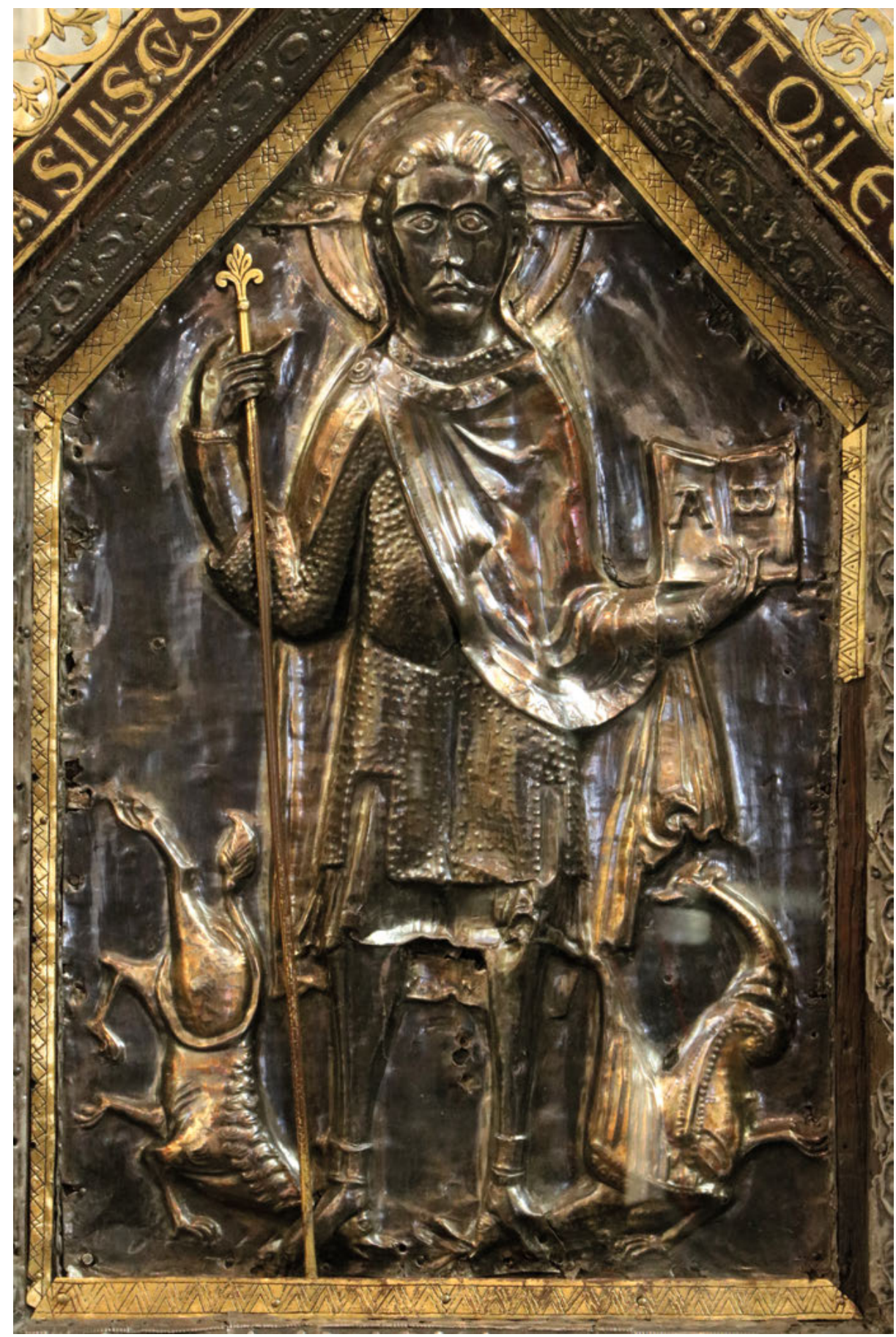

Fig. 1: Christus Victor, Visé shrine, gable-end. 


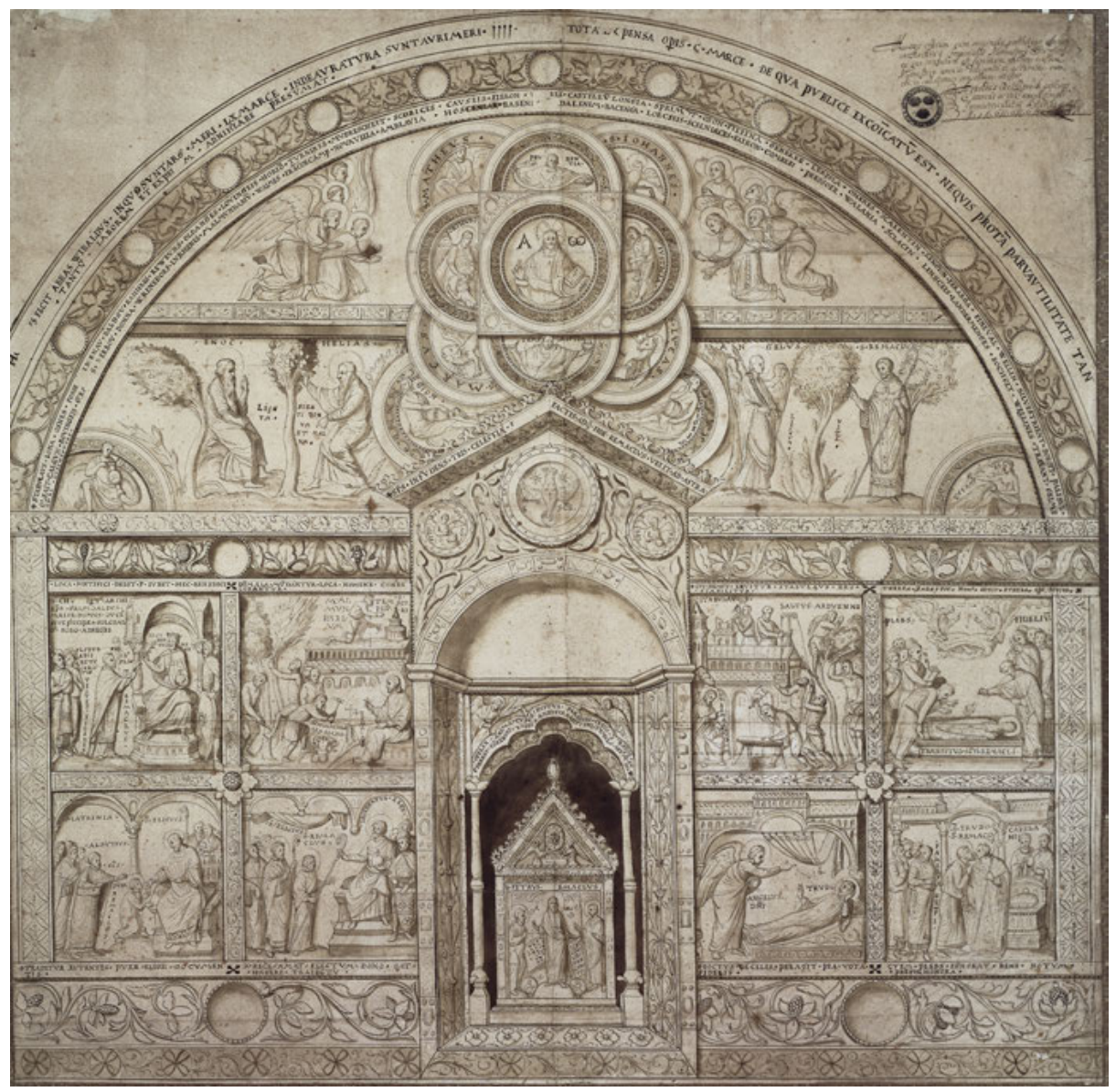

Fig. 2: Liège, Archives de l’État, drawing from 1666, altarpiece and first shrine of Stavelot-

well, including the gable ends of Visé and the first shrine of Stavelot that we know mainly from a seventeenth-century drawing (fig. 2). ${ }^{7}$ Based on these comparisons, it is possible to suggest that the rear gable end of the first shrine of St Remacle, not visible in this drawing, also included an image of the Christus Victor. This hypothesis is supported further by the adoption of this same iconography in the second shrine of St Remacle.

The theme of Christ triumphing over the malefic animals of Psalm 90 (91) mainly represents Christ's victory over the devil and over death at the moment of his Resurrection. We might wonder, however, why this iconography was associated with the altar. The shrines were positioned behind the altar and were consequently used as a

7 For the shrine of St Vanne, see Hugues de Flavigny, Chronicon, II, 374. For the altarpiece of Stavelot, see Wittekind 2004, 225-301; Lemeunier 2010; Kockerols 2016. 
sort of altarpiece. The first shrine of Stavelot, which was inserted into a huge altarpiece, confirms this connection. However, the gable end of the shrine depicted in the drawing is smaller than the arcade in which it was inserted, which gives reason to believe that the insertion took place at a later stage. ${ }^{8}$

The works of art presented in this paper were part of the liturgical space where the Eucharist took place, embedded in the sanctuary, and, at the same time, also served within the framework of the worship of saints. Occasionally, they were removed from the sanctuary in order to be carried in processions in and outside of the church, thus potentially following a sacred and symbolic topography. Unfortunately, there is little documented evidence of these processions.

\section{The Resurrection of Christ as a Paradigm for the Resurrection of the Saints}

It seems, Christ's triumph over death is echoed by the victory of the respective saints represented in the shrines, even if they are not martyrs. This is also indicated by the inscription on the gable end of the Vise shrine where Christ is shown crowning St Remacle and St Hadelin: "A crown sparkling of all its lights girds these conquerors of the world, famous by the glory of their triumph" ("Victores mundi preclaros laude triumphi hos diadema cluens circumdat vertice candens") (fig. 3). ${ }^{9}$ Both image and text present the saints as victorious figures who are being rewarded for their merits and are thereby reflecting Christ's victory over death through Resurrection.

The Resurrection of Christ can also be understood in relation to the relics preserved in the reliquary, as announcing the future resurrection of these saints. Several Mosan reliquaries show the resurrection of the dead, and two of them stage, in a completely exceptional way, the resurrection of the saints contained within. On the triptych of the True Cross in Liège, five haloed characters are represented as busts at the bottom of the central wing, under an arch with an inscription indicating that they represent the resurrection of saints at the end of time: RESVRRECTIO SANCTORVM.

The parallel with the Resurrection of Christ is particularly plausible as both triptychs of the Dutuit collection, which seem to be connected to that of Liège, show the Holy Women at the Sepulchre on an enamel occupying the same location, at the bottom of the central wing (ca. 1160-1180; fig. 5-6). On two of the four gable ends which originally flanked the shrine of St Servatius in Maastricht, St Monulphus and St Gondulphus are being resurrected. At the same time, they are receiving a crown from the Hand of God or from two angels, as is specified by the inscriptions that

8 Kockerols 2016.

9 Lemeunier/Didier 1988, 127. 


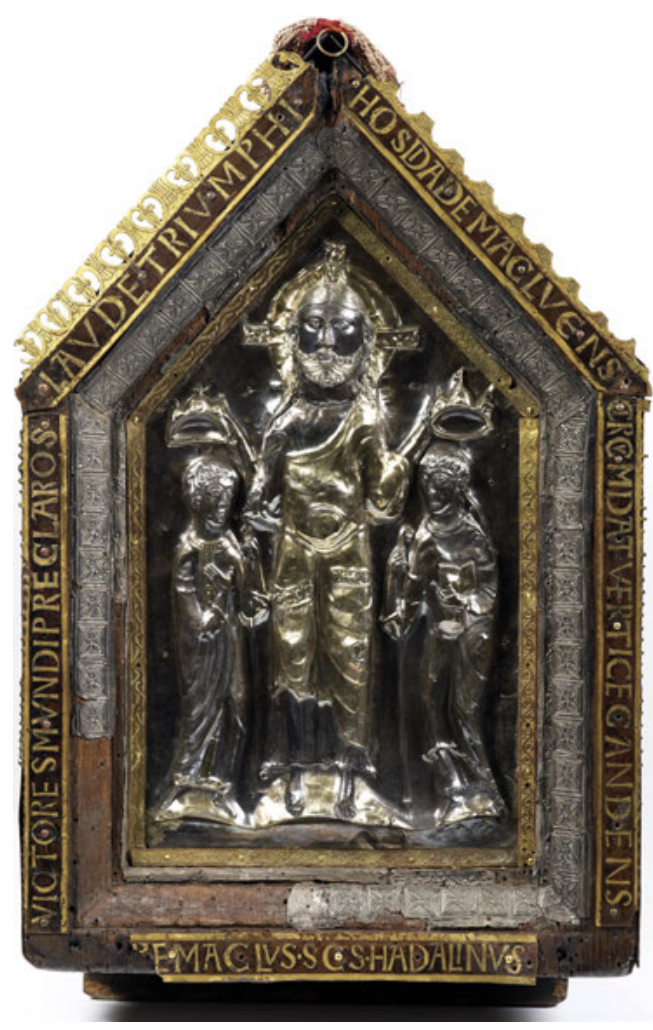

Fig. 3: Christ between Remacle and Hadelin, Visé shrine, gable-end.

accompany the scenes. Both gables combine the topics of the saints' coronation and their resurrection. This leads to the possible conclusion that the Christus Victor shown on one gable end of the Visé shrine also indicates the resurrection of St Remacle and St Hadelin, as their coronation is shown on the other end of the shrine.

Due to the reliquaries' association with the altars, some representations of the Christus Victor on the Mosan reliquaries may also be assumed to be connected with the Eucharist. As I have already suggested, this hypothesis may also apply to reliquaries of the True Cross and to the altarpiece of Stavelot, as they contain numerous epigraphic and visual elements explicitly referring to the Eucharist. ${ }^{10}$ In this paper, I would like to assess the extent to which this hypothesis applies to the Mosan representations of the Christus Victor. In order to support this interpretation on works in which the connection with the Eucharist is more explicit, I shall first approach the representations of Christ the Priest in medieval art, and then explore those objects which have been represented in the Rheno-Mosan artistic ambit. Finally, I will reflect on the programmes that integrate the theme of Christus Victor.

10 Angheben 2016a. 


\section{Christ the Priest in Medieval Art}

The priestly role of Christ is directly bound to the duplication of the Eucharistic liturgy celebrated on Earth. Every time a community of believers meets in its place of worship to celebrate the first sacrament of the church, at the time of the Preface, in the prayer preceding the canon, Christ descends from heaven with his angels. The latter intone the Sanctus along with the clergy, and, during the consecration, one of them brings the bread and the wine to the celestial altar so that they can be consecrated by Christ. ${ }^{11}$ In this moment the Son of God completely assumes the role of the High Priest, following the Order of Melchizedek. ${ }^{12}$ Thus, paradoxically, Christ represents the priest and the sacrifice at the same time. He embodies both the one who sacrifices and the one who is sacrificed, as stipulated by numerous liturgists, including Heriger of Lobbes and Alger of Liege. ${ }^{13}$ This double function is also referenced on the portable altar of Augsburg (1170-1180), in the inscription associated with the Crucifixion, which qualifies Christ as both presul and hostia: IN PRECIBVS FIXVS STANS PRESVL ET HOSTIA XPS (CHRISTVS). ${ }^{14}$ As in many inscriptions, the word presul can be read as bishop. ${ }^{15}$

These various notions are clearly visualised in sacramentaries and missals. The Preface and the Canon are illustrated by a theophany and a Crucifixion or a Tau, which corresponds to the first letter of the Te igitur, the fist prayer of the Canon, and at the same time to the shape of the cross. Christ suffering on the cross corresponds to the sacrifice made during the Canon. It can be assumed that Christ depicted in Majesty, in a mandorla, sometimes surrounded by the symbols of the evangelists, acts as a priest. The illustration of the Preface sometimes shows the angelic hierarchies about to sing the Sanctus, as in the Sacramentary of Charles the Bald (ca. 869-870) or the Sacramentary of St Denis (mid-11 ${ }^{\text {th }}$ century). Conversely, Christ sometimes holds a host in his right hand, as in the Sacramentary of Charles the Bald or in a French Romanesque missal. ${ }^{16}$ In the second missal of the Abbey of St Vindicien of Mont-Saint-Eloi, around 1250 , this role is represented even more explicitly by the blood flowing from the right hand of Christ into a chalice placed on an altar. ${ }^{17}$ It is hardly possible to envision the double role of Christ, as the priest and the sacrifice, in a more explicit manner. While

11 Jungmann 1956-1958, vol. 3, 21-158. In the $12^{\text {th }}$ century, the faithful participated less and less in the singing of the Sanctus, cf. Jungmann 1956-1958, vol.3, 39-40.

12 Bord 2013.

13 Heriger of Lobbes, De corpore et sanguine Domini, in: Migne, Jacques-Paul (ed.), Patrologia latina, vol.139, 187 B; Alger of Liège, De sacramentis corporis et sanguinis Dominici, I, 12, in: Migne, JacquesPaul (ed.), PL, vol.180, 778 B-C. See also Brigué 1936, 125-132.

14 Budde 1998, 66-73 (n 63).

15 Angheben 2016a, 196. See also the examples of the shrine of Saint Heribertus, cf. Seidler 2016, 94, 97.

16 Missel du Maine ou de Touraine (BnF, nouv. acq. lat. 2659, fo 2 r). For the interpretation of the discs held by Christ as hosts see Schapiro 1954, 313-315; Reynolds 2013.

17 Arras, Médiathèque municipale, ms. 38 (58), fo 105v-106r (Artois, ca. 1250), cf. Descatoire/Gil (eds.) 


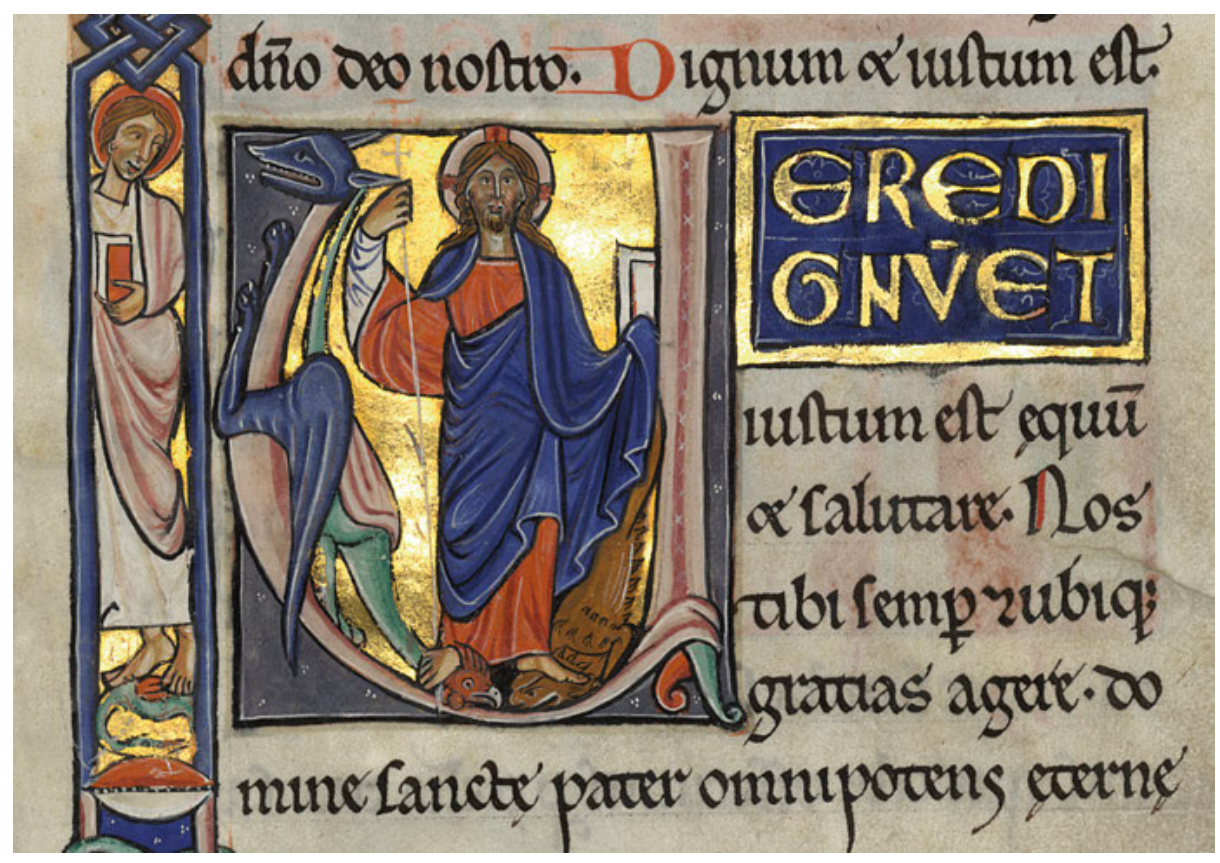

Fig. 4: Christus Victor, Pontifical of Chartres, Médiathèque d’Orléans, BM, Ms. 144, fo 71.

this image illustrates a prayer which is said every day, it also represents a part of the Last Judgement in which Christ acts as the Judge, flanked by the Virgin, St John and the other apostles, surrounded by the resurrection of the dead, hell and paradise. The work thus combines the sacerdotal and the judicial functions of Christ and, consequently, present and future times.

In the Chartres Pontifical, dating to the beginning of the $13^{\text {th }}$ century, the Preface has been illustrated by Christ standing, trampling the basilisk and the lion and piercing the first with his cross-staff (fig. 4). ${ }^{18}$ This image follows the traditional illustrations of the Preface and the Te igitur, namely a Maiestas Domini and a Crucifixion. It seems, consequently, that the Christus Victor combines the themes of Christ in Glory and his triumph over death.

An examination of the altar decoration is also of crucial importance for understanding Mosan reliquaries. In altar decoration, we often find a combination of Christ in Majesty and the Crucifixion, as in Scandinavian reredos (first half of the $12^{\text {th }}$ century) or in the altar front of Saint-Guilhem-le-Désert (first quarter of the $12^{\text {th }}$ century).$^{19}$ For the interpretation of Christ as a celestial priest, the most remarkable example is the

2013, 187-188. It must be noted that the two tablets of Moses are depicted on an altar on the other side of Christ, which means that the chalice also refers to the New Testament.

18 Orléans, BM, ms. 144, fo 71.

19 Kaspersen 2006, 80; Barral i Altet/Lauranson-Rosaz (eds.) 2004. 
altar of Ratchis in Cividale del Friuli (737-744), where Christ is accompanied by two angels. The angels' appearance combines the six wings of the seraph and the eyes on the wings of the cherub, and Christ wears a stole. ${ }^{20}$ This liturgical garment, worn by the officiating priest, also appears in a double-page illumination in the Uta Codex (ca. 1025). Here, Christ wears the stole while he is nailed to the cross, before a representation of St Erhard celebrating mass. ${ }^{21}$ It is also relevant to mention the antependium of Charles the Bald (mid-9 ${ }^{\text {th }}$ century), known from its depiction in a fifteenth-century painting when it had already been transformed into an altarpiece. ${ }^{22}$ Though Christ does not wear liturgical garments, two cherubs flying above him intone the liturgical Sanctus, different from that of Isaiah. This inscription consequently confirms that this celebration takes place during mass. Finally, the Catalan antependium of Ix shows Christ holding a host, as in certain manuscripts (second quarter of the $12^{\text {th }}$ century). ${ }^{23}$

\section{Christ the Priest in Mosan Art}

In Mosan metalwork, this Eucharistic meaning of Christus Victor can be suggested for the reliquaries of the True Cross. ${ }^{24}$ On the one hand, the majority of those that are completely preserved show, on the same vertical axis, the bust of Christ and the relics arranged in the shape of the cross as in the triptychs of Liège (c.1170), of the Guennol collection (1160-1170), and the reliquary of Tongres (1210-1220). These works also show some similarities with sacramentaries and altar decorations, namely emphasis on the Eucharist. On both triptychs of the Dutuit collection, the cross composed by the relics is clearly assimilated with the physical cross placed on the altar either permanently or at the beginning of mass (fig. 5-6), as both are shown above representations of altars with three nails on the little triptych and three candelabra on the large one. ${ }^{25}$ With these candelabra and the cross composed by the relics, the altar depicted on the large triptych seems to have been prepared for the celebration of mass and assimilated to the tomb of Christ depicted on the enamel of the Visitatio Sepulchri underneath.

20 Chinellato 2010; Chinellato 2016.

21 Cohen 2000, 65-75

22 Gaborit-Chopin 1991, 49-50.

23 Castiñeiras 2008.

24 I discuss this topic further in Angheben 2016a.

25 Stratford 1993, 81-82, challenges the authenticity of these triptychs. This authenticity is defended by Holbert 1995, 123-129. Then, it is demonstrated by Biron/Morel/Borel 1998. See also Descatoire/Gil (eds.) 2013, 81; Biron 2015, 233-269. Sophie Balace has kindly pointed out to me that a sales catalogue of the Renesse-Breidbach collection, prior to the Soltykoff sale of 1861, mentions only one triptych. The result is that some uncertainty remains about the history of the two triptychs. 


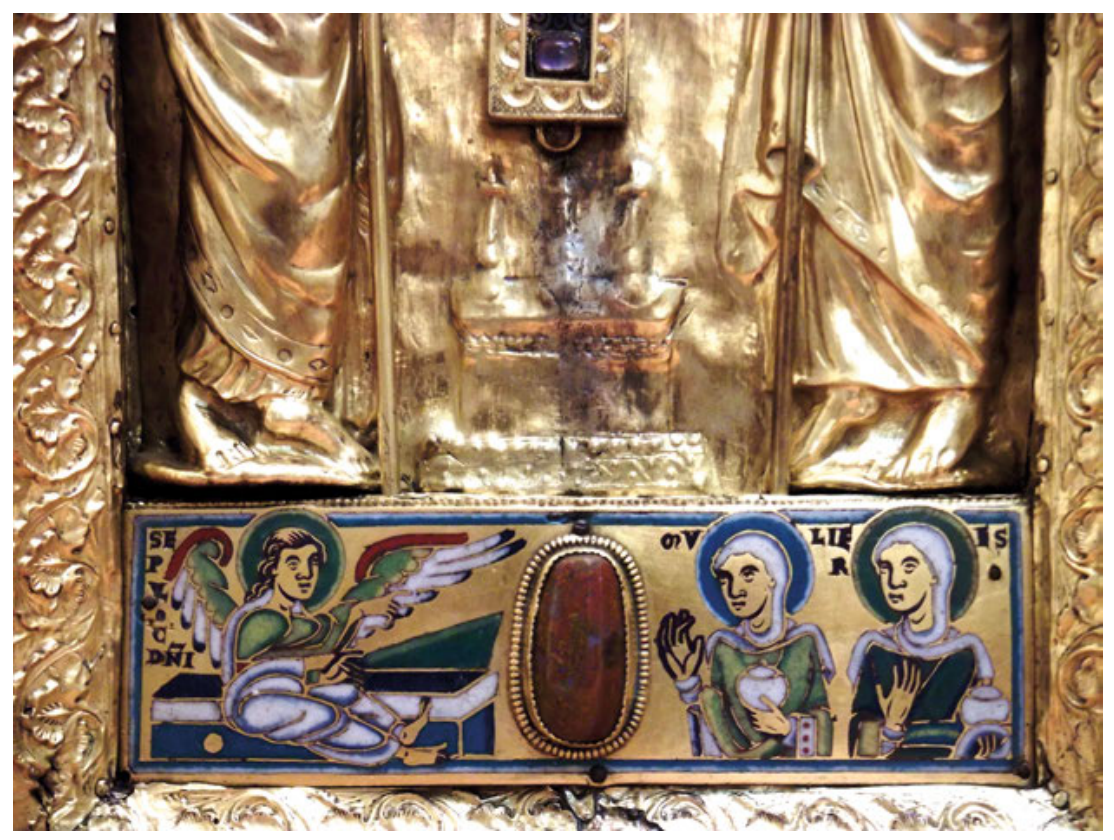

Fig. 5: Visitatio Sepulchri, large triptych of the True Cross, Paris, Petit Palais.

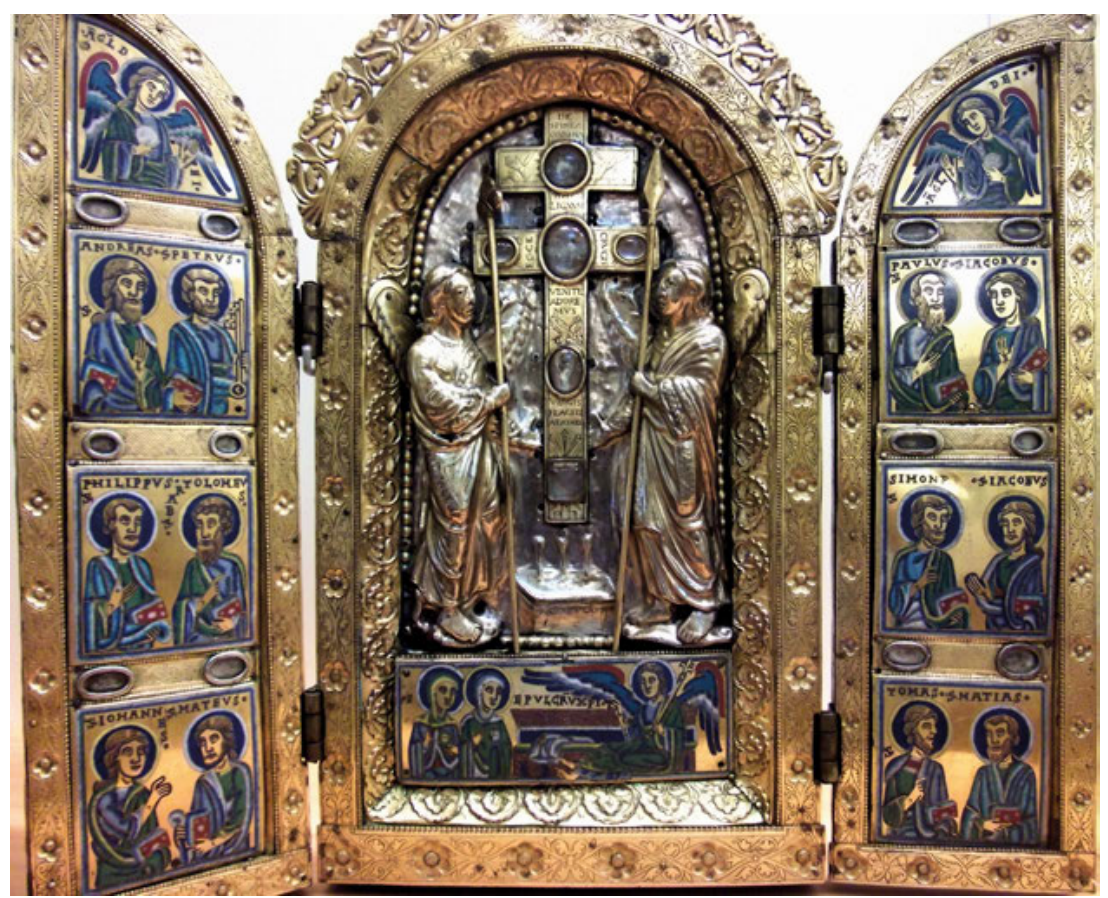

Fig. 6: Small triptych of the True Cross, Paris, Petit Palais. 
In both triptychs, two angels located at the top of the lateral panels take part in this celebration. We can suppose that those of the larger triptych are singing the Sanctus, even though the inscription, contrary to what happens on Charles the Bald's antependium, does not specify whether this is the liturgical chant: SCS SCS. The angels on the small triptych hold small, white loaves of bread or hosts in their hands. One might assume that these objects correspond to globes since angels often hold these attributes, but the Rheno-Mosan goldsmiths established a clear difference between such globes and hosts. They gave volume to the globes by means of a colour gradient as in the shrine of St Heribert, in Deutz, while others adopted flat, white shapes for the loaves of bread or hosts depicted in several iconographic contexts referring to the Eucharist: the Last Supper in the portable altar of Stavelot (1150-1160), the personification of Spes exhibiting a chalice and a host on the cross of Baltimore (1150-1175), or the sacrifice of Melchizedek on the pulpit of Klosterneuburg (1181).

It thus seems that the angels are carrying the Eucharistic bread from the terrestrial altar to the celestial one, so that the Christ-Priest can consecrate it, as specified in the Supplices, one of the prayers of the Canon of the Mass:

Most humbly we implore Thee, almighty God, bid these our mystic offerings to be brought by the hands of Thy holy Angel unto Thy altar above, before the face of Thy divine majesty; that those of us who, by sharing in the Sacrifice of this altar, shall receive the most sacred Body and Blood of Thy Son, may be filled with every grace and heavenly blessing. ${ }^{26}$

The function of the angel, as described in this prayer, is emphatically visualised in the breviary of Aldersbach, where he seizes the Christ-Child emerging from the host raised by the priest. ${ }^{27}$

On the triptych of Florennes (1200-1210) and the reliquary of Tongres (1210-1220), the relics of the True Cross are arranged according to the visual framework of a Crucifixion, flanked by a personification of the church holding a chalice. ${ }^{28}$ This liturgical object is generally considered as a simple attribute identifying the church through its first sacrament. However, as an object used during mass, the chalice clearly refers to the community of the faithful taking part in the Eucharist. This association is also suggested in the portable altar of Augsburg, where the Crucifixion is flanked by a personification of the church, since Christ is portayed as both priest and sacrifice. Moreover, the Mosan reliquaries of the True Cross also display angels as thurifers, probably to signify that angels take part invisibly in the act of the incensing of the altar after the offertory, as suggested by the wall paintings of Sant Quirze de Pedret. ${ }^{29}$

26 Deshusses 1971, 90.

27 Garhammer 2000.

28 Balace 1999; Balace 1999c, 52; Balace 2009, 371-374.

29 Angheben 2016b. 


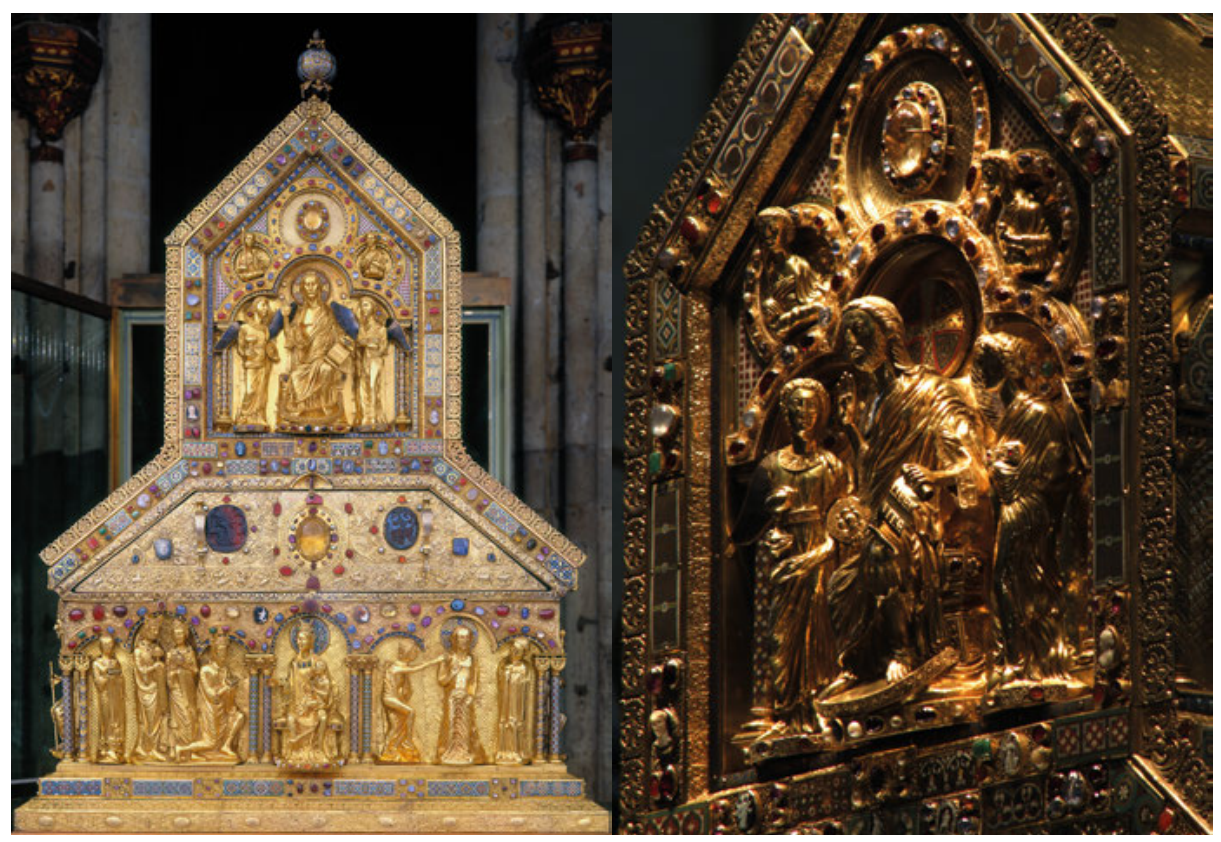

Fig. 7: Cologne, shrine of the Three Kings, main gable end and detail.

The Guennol triptych is the only one to visually suggest the role of Christ as a priest. ${ }^{30}$ At first sight, the viewer encounters the image of Christ as a judge presiding over the Last Judgement taking place at his feet. But when the wings are closed, that is, during a large part of the liturgical year, Christ is the only iconic component which remains visible. Furthermore, the vase of vinegar, one of the instruments of the Passion usually carried by angels during the Parousia, is represented as a chalice. We can thus suggest that here Christ embodies both roles as a priest and a judge at the same time, which can be compared to the Missal of Saint-Vindicien.

The main gable end of the shrine of the Three Kings in Cologne leads to a similar conclusion (fig. 7). On the upper register, Christ is flanked by two angels next to him, and the archangels Gabriel and Raphael appear in medallions above him, formerly accompanied by St Michael. ${ }^{31}$ Three of these angels exhibit one of the instruments of the Passion and the inscription of the trilob arch amplifies this topic by enumerating these signa and specifying that the one who judges the merits of each suffered from them:

30 Monroe 1992; Holbert 1995, 140-183; Bagnoli/Klein/Mann/Robinson (eds.) 2010, 180-181; George 2013, 250.

31 For the inscriptions and their authenticity, see Kemper 2014, vol.3, 61-62, 74-74. See also Ciresi 2003; Ciresi 2005; Lauer 2006. 
The angel standing to the right of Christ holds a chalice also mentioned by this titulus, and a paten. The inscription under the cornice confirms that the instruments of the Passion are exhibited in the context of the Last Judgement, evoking the salvation and the joy reaped by the righteous, and the fire into which the evil are thrown:

ADVENIO DIGNOS SALVARE FERIRE MALIGNOS + ERGO BONI METITE FELICIA GAVDIA VITE + ITEREI VOS IRA DEI TRANSMITTIT IN IGNE QVISQ METIT QVOD PROMERVIT SVB IVDICE IVSTO

The theme of the Last Judgement was extended on the former panels of the roof of the shrine, and it can be assumed that the apostles aligned on the upper register of the long sides played the role of the assessors, as can also be assumed about the shrine of St Servatius at Maastricht, which shows a similar arrangement. ${ }^{32}$

If the composition of the upper register of the main gable refers clearly to the end of time, the angel holding a chalice and a paten evokes the Eucharist. The angle seems to fulfil the role of the angel of the Supplices, who carries the bread and wine to the celestial priest. This iconography can also be found in the breviary of Aldersbach, mentioned before, and on the Mosan cross now in Baltimore, where an angel presents a host and a chalice as attributes. In the latter, however, these elements signify Christ as the sacrificed one, not Christ as the one carrying out the sacrifice.

In the case of the Cologne shrine, the theme of the Last Judgement and that of the Eucharist are combined. This dynamic corresponds to a tendency that can be observed in the Mosan goldsmith work of the second half of the $12^{\text {th }}$ century and which increases in the first half of the following century, as we have seen with the Guennol triptych and the Missal of Saint-Vindicien. The portal of Saint-Sulpice-de-Favières, where Christ of the Last Judgement holds a chalice, and the central stained-glass window of the Cathedral of Châlons-en-Champagne, where he pours his blood into a chalice placed on its throne-altar (ca. 1240-1250; fig. 8), serve as further examples. ${ }^{33}$

Thus, in these compositions, the current temporality of the performance of the liturgical act seems to be associated with that of the Parousia, followed by eternity, in order to show that the elect will forever celebrate the celestial liturgy with saints and angels. In the Cologne shrine, the connection with the liturgy of the altar is visually confirmed by the "procession of the Kings", conceived as an offertory procession taking place in the lower part of the shrine. The Kings are indeed followed by the Emperor Otto IV, who offers the gold used to make that particular part of the reliquary. In this way, the Emperor is equated, as suggested by liturgists since Honorius Augus-

32 For the shrine of Maastricht, see Kroos 1985; Angheben 2016c.

33 Fusier/Philippot 2005, 74-75; Angheben 2016d, 162; Angheben 2013, 162. 


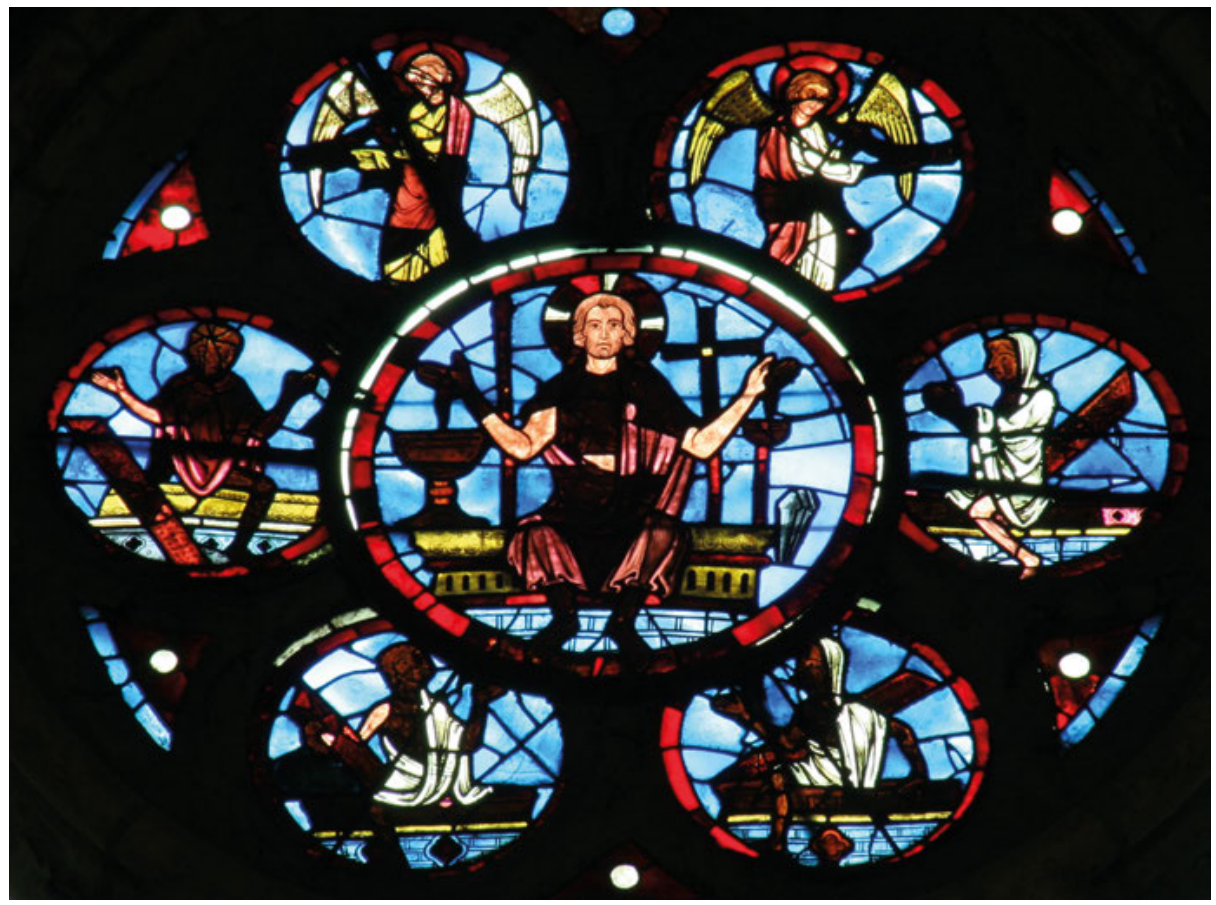

Fig. 8: Resurrection of the death, Châlons-en-Champagne, cathedral, stained-glass of the central window of the choir, (ca. 1240-1250).

todunensis, with the first King who also offers gold. ${ }^{34}$ It is important to note that the Eucharistic meaning of the programme emanates exclusively from the images and not from the inscriptions.

\section{The Christus Victor in the Mosan Shrines}

\subsection{The Gable Ends of Visé and Amay}

It is now necessary to explore whether the Christus Victor assumes a priestly function. The depiction of the Lord overcoming death relates to both Christ suffering on the cross and triumphing at the moment of his Resurrection. The inscriptions of the shrine of Visé confirm this double meaning by speaking of Christ suffering the Passion on the cross as a king: " $O$ famous warlike king, by dying on the cross, the basilisk and the

34 Honorius Augustodunensis, Gemma animae, I, 27, in: Migne, Jacques-Paul (Hg.), PL, vol.172, 553 A-B. Angheben 2012, 36-39. 
treacherous asp and the lion are submitted to you" ("Belliger insignis tibi sic basiliscus et aspis subdolus atque leo subeunt rex in cruce passo")..$^{35}$ The inscription thus mentions the cross, which is usually present on the triptychs of the Real Cross, but almost never depicted on the gable ends of the shrines. The first shrine of Stavelot, which was destroyed in the $18^{\text {th }}$ century, contained relics of the True Cross, and the one of Cologne hosts a Crucifixion on the rear gable, however, the subject is never depicted on the main gable. We could thus suggest that the theme of the Christus Victor is used to evoke the Crucifixion without representing it. A similar theme appears on the reliquary of the True Cross of Nantes, where the cross dominates a reptile called "snake" ("serpens"). As Philippe Verdier clearly demonstrated, this type of Crucifixion echoes the Christus Victor in representing the Lord victorious over the devil and over death. ${ }^{36}$ Furthermore, it reinforces the hypothesis that Christ trampling the malefic animals is used to evoke the Crucifixion without representing it.

It is more difficult to establish that the evocation of the Death and Resurrection of Christ refers to his priestly function. Like the destroyed antependium of Verdun, the gables of Visé and Amay are connected with the holy table. And the Pontifical of Chartres, though dated much later than the first Mosan shrines, shows that Christ standing and piercing the malefic animals of Psalm 90 (91) can implore both scenes, the theophany and the Crucifixion that usually decorate the texts of the Preface and of the Te igitur, at the same time. However, the gables of those shrines do not provide iconographic or epigraphic clues, which would allow the same significance to be attached to them.

It seems certain that both older examples of Christus Victor refer to the Resurrection, thereby offering the faithful an image of the paradigm of the saints' victory over death-since they are rewarded with a crown in the Visé shrine-as well as a model for the future resurrection of their bodies, which are partly preserved in the reliquary. This is all the more likely since the theme is brought up on three reliquaries of the True Cross. The triptych of Liège establishes a strong correlation between the presence of corporal relics and a quite realistic depiction of the resurrection of the saints. As for both triptychs of the Dutuit collection, they evoke the Resurrection of Christ in the form of the Visit of the Holy Women at the Sepulchre.

\subsection{The Shrine of St Eleutherius in Tournai}

The Eucharistic interpretation can however be assumed for both more recent examples: the shrine of St Eleutherius in Tournai and the second shrine of Stavelot. Christ is enthroned and tramples a lion and a dragon in the Tournai shrine (fig. 9) and only

35 Lemeunier/Didier 1988, 122.

36 Verdier 1982, 74. 


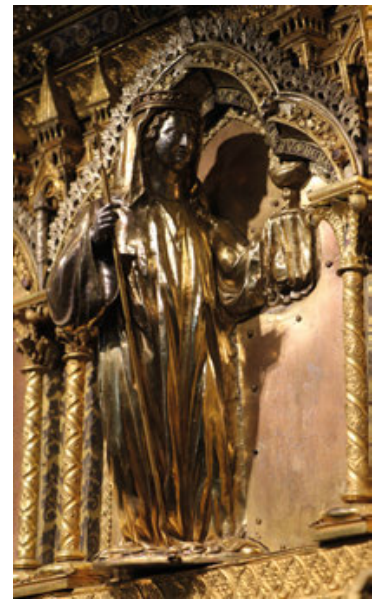

Fig. 10: Allegory of the Church, Tournai, cathedral, shrine of Saint Eleutherius, roof.

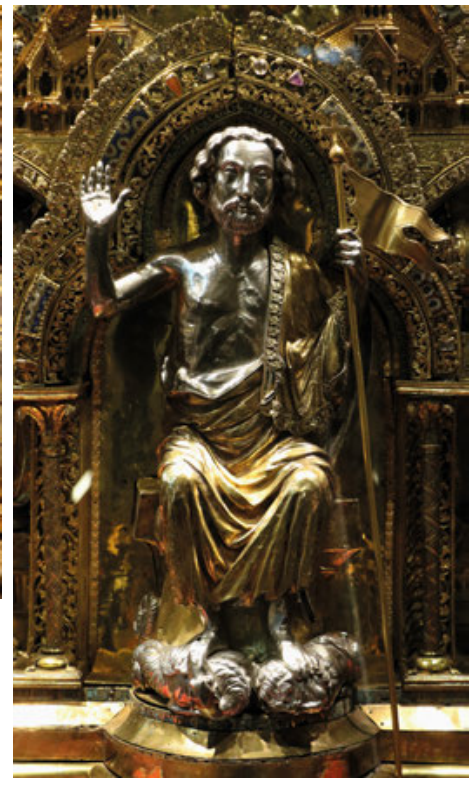

Fig. 9: Christus Victor, Tournai, cathedral, shrine of Saint Eleutherius, gable-end.

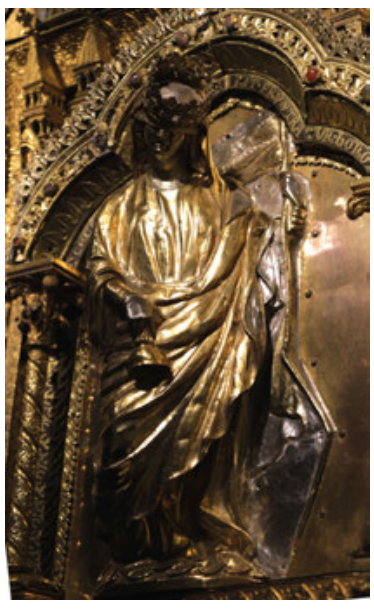

Fig. 11: Allegory of the Synagogue, Tournai, cathedral, shrine of Saint Eleutherius, roof.

a dragon in the second shrine of Stavelot. In the former, he is also surrounded by angels; one amongst them, at the top of the composition, holds the instruments of the Passion (fig. 9). Unlike the shrine of Cologne, this one evokes the Second Parousia without representing the other components of the Last Judgement, such as the resurrection of the dead, the weighing of the souls, the corteges of the elect and the damned, heaven and hell. But, as for the Cologne shrine, this is not the only possible significance of this depiction, as the animals of Psalm 90 (91) refer to the Passion and to the Resurrection. The theme of the Last Judgement has been associated with the Passion and, more precisely, with the Crucifixion, as suggested by the inscription of the reliquary of Visé. This choice is in line with the iconographic tradition initiated in the Last Judgement of the southern portal of the Cathedral of Chartres where the Judge appears under a cross, next to both main protagonists of this event: the Virgin and John the Evangelist. ${ }^{37}$

On the roof of the shrine of Tournai, the theme of the Crucifixion is also referred to by the personifications of Ecclesia and Synagogue, who very often accompany the

37 In the depiction of the Last Judgement, the link between Christ and the cross had been established since the $10^{\text {th }}$ century, but it is on the southern portal of Chartres (ca. 1210) that it began to acquire such an importance, cf. Angheben 2013. 
representations of this episode (fig. 10-11). ${ }^{38}$ The tie between Christ and Ecclesia is all the more evident as she is situated on his right side while Synagogue is placed to his left. Ecclesia holds a chalice, which is one of her main attributes. The accompanying inscription explicitly mentions the blood of Christ which cures the church: "Presidet Ecclesia Christi relevata cruore". In this context, the chalice reinforces the link between Christus Victor and the Crucifixion, as the blood contained in the chalice stems from the wound in the side of Jesus' chest. More surprisingly, instead of holding the Tablets of the Law or the instruments of the Passion, Synagogue holds an upsidedown chalice, following the example of the foolish virgins spilling the oil of their lamps. This iconography clearly suggests that the offerings of Synagogue have been refused (even if we ignore the contents of the chalice), while the sacrifice of Ecclesia has been accepted. Given that the designer chose to assign a chalice to both Ecclesia and Synagogue, which is absolutely exceptional, we can be certain that the visual programme not only represents the Passion and the institution of the church as such, but also places great emphasis on the Eucharist. This is all the more likely since, in Mosan art, the representations of Ecclesia are generally connected with the sacrament.

In addition to the triptych of Florennes and the reliquary of the Holy Cross of Tongres, mentioned previously, it is necessary to consider the portable altar of Stavelot, where the allegory dominates a quatrefoil that evokes the cross, surrounded by Old Testament scenes referring to the Eucharist and taken from the prayer Supra quae: the sacrifices of Abel, Abraham and Melchizedek. ${ }^{39}$ A similar scheme can be found in the stained-glass window of Châlons-en-Champagne that probably initially decorated the axial window of the cathedral dedicated in $1150 . .^{40}$ Finally, in the cross of Scheldewindeke (ca. 1170-1180), which we must imagine placed on an altar, the allegorical figure of Ecclesia holds a chalice and, what is exceptional, a host marked with a cross placed on a paten. ${ }^{41}$ When she appears in the decoration surrounding the altar, the personification of the church can consequently be interpreted as an evocation of the local community gathered around its first sacrament. And in the case of the Tournai shrine, Ecclesia brandishes the chalice not towards the spectator but towards Christ, making it similar to the gesture of the angel of the Supplices of Cologne, which presents a chalice and a paten to Christ in the skies for him to consecrate the contents.

Based on this interpretation, we can understand another component of the shrine. Its roof presents the Annunciation flanked by John the Baptist showing a medallion with the Lamb of God. This depiction could evoke the Eucharist as hosts were often decorated with the animal of the sacrifice. The same theme appears on the exterior of the right wing of the triptych of Florennes. Furthermore, on the cross of Scheldewindeke, the medallion is held by an angel, thus associating it even more precisely with a

38 Verdier 1982 82-83; Asch 2013, 65-66.

39 Gudera 2003; Wittekind 2004, 51-172; Henriet 2016.

40 Fusier/Philippot 2005, 65-70.

41 Musées royaux d'Art et d'Histoire of Brussels, see Balace 1999b, 28. 
host. The most important aspect, however, is that the presence of Ecclesia and Synagogue holding a chalice on either side of Christ suggests the Eucharistic interpretation of Christus Victor, which we might then apply to other artworks.

\subsection{The Stavelot Shrine}

The second shrine of Stavelot does not contain epigraphic or iconic components supporting this hypothetical priestly interpretation of Christ (fig. 12-13). The related inscription refers to his capacity as a Creator and sovereign: SOLVS AB ETERNO CREO CVNCTA CREATA GVBERNO. The presence of the college of the apostles might, on the contrary, be connected to a prayer of the Canon of the Mass, the Communicantes. This prayer invokes the intercession of the Virgin, the apostles and the saints, some of whom are named. As rightly highlighted by Clemens Bayer, the apostles are listed in the same order as in the Stavelot shrine, which thereby evokes precisely this specific prayer. ${ }^{42}$ In addition, this might show specifically that the celestial church is present in the middle of the terrestrial community at the moment of the Canon of the Mass. In such a context, Christ might have held the role of the high priest, in addition to his role as Creator and celestial sovereign proclaimed by the inscription.

If we consider the programme from a Eucharistic point of view, we can also interpret some scenes of the life of Christ depicted on the roof in the same way. In the Nativity, the manger adorned with filigree could have been assimilated with an altar. In the Adoration of the Magi, the first one seems to hold a pyx, like both last kings of the Cologne shrine. In the Presentation of Jesus at the Temple, the Virgin and Simeon are holding the Child above an altar. Cups in the form of a chalice are laid on the table of the Last Supper in which the Eucharist has been instituted. Finally, the personification of the church holds a chalice in the Crucifixion (fig. 14).

\subsection{The Problem of the Inscriptions}

The iconographic clues provided by the shrines of Cologne, Tournai and Stavelot suggest that their programmes refer both to the cult of the titular saint and to the sacrament of the Eucharist celebrated on the altar for which the reliquary served as an altarpiece. However, the epigraphy does not designate Christ as the high priest of the celestial liturgy. The same applies to the examples in which this role is testified to by the iconography and, sometimes, also by the context: the sacramentaries, the missals, the Guennol triptych and the stained glass of the choir of the Cathedral of Châlons-en-Champagne (ca. 1240-1250). The Evangeliary of the Sainte-Chapelle and

42 Bayer 2014. 

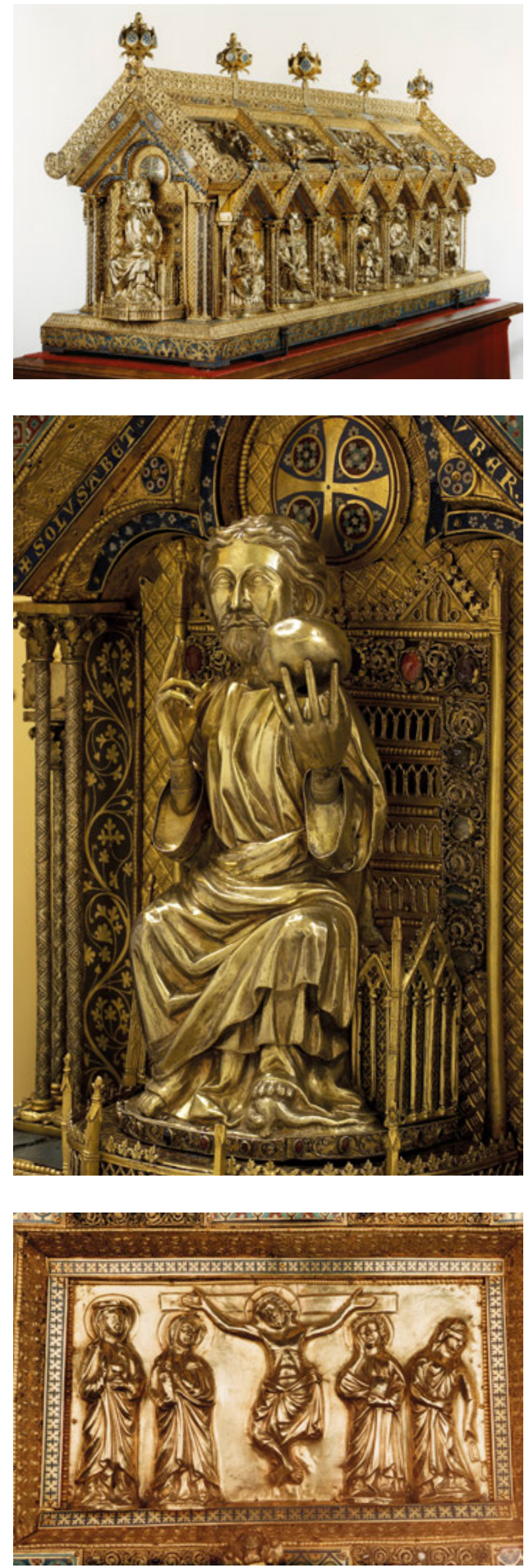

Fig. 12: Stavelot, shrine of Saint Remacle.

Fig. 13: Christ trampling the dragon, Stavelot, shrine of Saint Remacle, gable-end.

Fig.14: Crucifixion, Stavelot, shrine of Saint Remacle. 
the northern portal of the west facade of the Cathedral of Bayeux may be added to this list. ${ }^{43}$ Only few exceptions clearly qualify Christ as a pastor or presul, as can be seen on the lantern of Begon in Conques and on the portable altar of Augsburg, but not as sacerdos. ${ }^{44}$ It can thus be assumed that this function was obvious and did not need such a specific inscription to clarify its meaning.

In the case of five Rheno-Mosan shrines, Christ is associated with generic inscriptions glorifying his almighty power or his kingship. In the shrine of St Heribertus in Deutz (1175), he holds a book quoting a passage from Exodus in which God reveals his name to Moses, thereby establishing absolute equality between Father and Son: EGO SVM QVI SVM. ${ }^{45}$ In the shrine of Notre-Dame of Tournai (1205), the inscription, which is only partly preserved, claims his royal status feared by the infernal world and implored by the supernal order: REX EGO SVM ... ME TREMIT INFERNO MIHI SUPPLICAT ORDO SVPERNVS. ${ }^{46}$ The mention of hell possibly evokes the Last Judgement since the angel's hands are veiled and should therefore hold instruments of the Passion, similar to those given to them by the restorer. In the shrine of Charlemagne in Aachen (1215), Christ, inscribed in a medallion dominating the emperor, is presented as the one who remains in his government and sets everything in motion: CVNCTA REGENS STABILISQ[VE] MANENS DO CVNCTA MOVERI. ${ }^{47}$

In the shrine of Notre-Dame of Huy (ca. 1265), which is very similar to the one of Stavelot, Christ pronounces the words of John's Gospel (Jn 14,6): EGO S(VM) VIA ET VERITAS ET VITA. ${ }^{48}$ And as already referred, the Stavelot shrine presents Christ as a sovereign and as the Creator: SOLVS AB ETERNO CREO CVNCTA CREATA GVBERNO. If we assume that Christ actually plays the role of a high priest, we must infer from this that the designers did not find it necessary to specify this meaning through the epigraphy. They would therefore have chosen the inscriptions to glorify Christ's almighty power so as not to exclude any aspect of his character and to be able to integrate, in this manner, his power to transform bread and wine into his flesh and his blood. This explanation is not fully satisfactory, especially since the inscriptions of the Cologne shrine refer directly to the iconography. However, I can see no other explanation for this divergence between image and text, unless of course the priestly interpretation of Christ is erroneous.

This interpretation relies on three major points. Several altar decorations present iconographic or epigraphic clues attesting to Christ's priestly function, suggesting that this signification can be applied to the majority of the works including a depiction of Christ above the altar. The Christus Victor of the Chartres Pontifical shows

43 Gauthier 1976, p. 160; Schlicht/Angheben 2016, 241-243.

44 Pour l'autel de Bégon, see Favreau /Michaud/Leplant 1984, 47-48.

45 Seidler 2013, 101.

46 Navez 2005, 124-127.

47 Deutsche Inschriften Online, DI 31 Aachen Dom (1992), $\mathrm{n}^{\circ} 34$.

48 Van den Bossche 2000; Lemeunier 2012, 20-23. 
that this theme was equally able to show Christ as a priest and as the crucified sacrifice. Finally, the Tournai shrine shows Ecclesia presenting a chalice to Christ and an exceptional representation of Synagogue holding the same liturgical vessel upside down. This interpretation can therefore be considered for this work and can also be extended to the Stavelot shrine. It may also be carefully envisioned for the gable ends of Visé and Amay, and for the depictions of Christ enthroned in the other Rheno-Mosan shrines.

\subsection{Mosan Shrines and Sacred Space}

We do not know in which direction the reliquaries set up behind the altars were oriented, and, consequently, which side was visible to the clergy. The drawing of 1666, showing the altarpiece of Stavelot, suggests that the gable end erected behind the altar included a depiction of Christ, in this case accompanied by St Remacle. This would mean that if the saint was not represented on the main side, he would only have been visible from the rear, and that the faithful would have been invited to walk around the altar, either by entering the ambulatory, if there was one, or by any other specific device adapted to the needs of the community and to the constraints of the architecture. For the first shrine of Stavelot, which was framed by an altarpiece, it has been assumed that it was inserted into the wall of the ambulatory in such a way that both gables could be seen respectively from the ambulatory and from the crypt. However, it is however impossible to confirm this hypothesis. ${ }^{49}$ Finally, it is possible that on the occasion of the feast of the saint, the orientation of the shrine was temporarily inverted in order to make the saint's image visible to the clergy.

Whatever the case, it can be assumed that most of the time, the main side showed Christ in Majesty. This hypothesis can be supported in particular for the shrines of Tournai and Stavelot as one of the two gables is occupied by an isolated saint: Eleutherius in the former and the Virgin in the latter. It is indeed unlikely that the sight of the divine figure would have been denied the clergy. If we suppose that the gable end dedicated to Christ adorned the altar in the manner of an altarpiece, it would seem obvious that the iconography and the inscriptions of these two reliquaries establish a correlation between the terrestrial and the celestial church, embodying the latter in the space of the sanctuary. Christ could then be associated with the priest celebrating mass at the terrestrial altar and also with the bread and the wine he is about to sacrifice at the celestial altar, once they have been brought by the angel of the Supplices. The angels surrounding Christ would reflect the clergy singing the Sanctus, right after the Preface. Finally, the apostles and the saints depicted on the other sides would

49 This hypothesis was supported by Lambotte 2014. Doubts were expressed by D'Hainaut-Zveny 2014, 103-104. Kockerols 2016, 217, rejected this hypothesis. 
complete the image of the celestial church and echo the local community of faithful gathered around his clergy. This is all the more likely since the architecture of the shrine corresponds to the forms of a gothic church in such a way that the consecrated space echoes the Heavenly Jerusalem which houses the members of the celestial church.

During the time of the consecration, the ecclesiastical space would temporarily become that of the union of the two churches, the terrestrial and the celestial one, which will be reunited at the end of time. This connection, again, explains why the theme of the Last Judgement was linked to Christ as high priest. Through the combination of images and texts connected to both the present and the future, the sanctuary appears in any case as the place of the temporary unification of the two churches, which announces their final and eternal union.

\section{Bibliography}

Alger of Liège, De sacramentis corporis et sanguinis Dominici, in: Jacques-Paul Migne (ed.), Patrologia latina, vol. 180.

Angheben, Marcello (2012), “La Vierge à l'Enfant comme image du prêtre officiant. Les exemples des peintures romanes des Pyrénées et de Maderuelo", in: Codex aquilarensis 28. Creer con imágenes en la Edad Media, 29-74.

Angheben, Marcello (2013), D'un jugement à l'autre. La représentation du jugement immédiat dans les Jugements derniers français: $1100-1250$, Turnhout.

Angheben, Marcello (2016a), “Les reliquaires mosans et l'exaltation des fonctions dévotionnelles et eucharistiques de l'autel”, in: Codex aquilarensis 32, 171-208.

Angheben, Marcello (2016b), “Les peintures de Sant Quirze de Pedret: un programme apocalyptique au service de l'eucharistie", in: Les cahiers de Saint-Michel de Cuxa 47, 51-67.

Angheben, Marcello (2016c), "Du transitus à la résurrection : la représentation de la destinée posthume des saints dans l'orfèvrerie mosane”, in: Philippe George (ed.), Orfèvrerie septentrionale (XII' \& XIII' siècle), Liège, 11-31.

Angheben, Marcello (2016d), "Résonances sacramentelles, dévotionnelles et sensorielles des images : la Vierge à l'Enfant et la Crucifixion sur les vitraux du Mans", in: Stephanie Diane Daussy/ Nicolas Reveyron (eds.), L’Église, lieu de performances. “In locis competentibus”, Paris, 159-179.

Asch, Léopold (2013), L'Église et la Synagogue dans l'art médiéval. Étude iconographique, Colmar.

Bagnoli, Martina / Klein, Holger A. / Mann, C. Griffith / Robinson, James (eds.) (2010), Treasures of Heaven. Saints, Relics, and Devotion in Medieval Europe, Cleveland/London.

Balace, Sophie (1999a), “La staurothèque de Tongres”, in: Bulletin des Musées Royaux d'Art et d'Histoire, 70, 149-185.

Balace, Sophie (1999b), “Croix de Scheldewindeke”, in: Dumortier 1999, 28.

Balace, Sophie (1999c), “Triptyque de Florennes”, in: Dumortier 1999, 52.

Balace, Sophie (2009), Historiographie de l'art mosan, Thèse de doctorat, Université de Liège, 2009. Barral i Altet, Xavier / Lauranson-Rosaz, Christian (eds.)(2004), Saint-Guilhem-le-Désert. La fondation de l'abbaye de Gellone. L'autel médiéval, Actes de la table ronde d'août 2002, Aniane.

Bayer, Clemens (2014), "Sur la datation de la châsse de saint Remacle : deux missives et des inscriptions”, in: Benoît van den Bossche / Alain Dierkens / Nicolas Schroeder (eds.), À la recherche 
d'un temps oublié. Histoire, art et archéologie de l'abbaye de Stavelot-Malmedy au XIII' siècle. Actes du colloque organisé en mai 2012, Stavelot, 87-94.

Biron, Isabelle / Morel, Dominique / Borel, Thierry (1998), “Les triptyques reliquaires Dutuit : de l'œil du connaisseur à l'examen de laboratoire. Histoire d'une réhabilitation”, in: Technè, 8, 97-106.

Biron, Isabelle (2015), "Les émaux mosans, rhénans et affiliés. Champlevés sur cuivre. XIIe - début XIII' siècle", in: Isabelle Biron (ed.), Émaux sur métal du IXe au XIXe siècle. Histoire, technique et matériaux, Dijon, 233-269.

Bord, Lucien-Jean (2013), Melchisédek: formation, histoire et symbolique d'une figure biblique, Paris.

Brigué, Louis (1936), Alger de Liège. Un théologien de l'eucharistie au début du XIIe siècle, Paris.

Budde, Michael (1998), Altare portatile. Kompendium der Tragaltäre des Mittelalters, 600-1600, Münster.

Castiñeiras, Manuel (2008), “Entorn als orígens de la pintura romànica sobre taula a Catalunya : els frontals d'Urgell, Ix, Esquius i Planès”, in: Butletí del Museu Nacional d'Art de Catalunya, 9 , 17-41.

Chinellato, Laura (2010), “L'Altare di Ratchis”, in: Valentino Pace (ed.), L'VIII secolo: un secolo inquieto. Atti del Convegno internazionale di studi. Cividale del Friuli, 4-7 dicembre 2008, Cividale del Friuli, 83-91.

Chinellato, Laura (2016), L'ara di Ratchis a Cividale : la ricerca e la riscoperta delle policromie, Udine.

Ciresi, Lisa Victoria (2003), "A Liturgical Study of the Shrine of the Three Kings in Cologne”, in: Colum Hourihane (ed.), Objects, Images and the Word. Art in the Service of the Liturgy, Princeton, 202-230.

Ciresi, Lisa Victoria (2005), "Of Offerings and Kings: The Shrine of the Three Kings in Cologne and the Aachen Karlsschrein and Marienschrein in Coronation Ritual”, in: Bruno Reudenbach / Gia Toussaint (eds.), Reliquiare im Mittelalter, Berlin, 165-185.

Cohen, Adam S. (2000), The Uta Codex. Art, Philosophy, and Reform in Eleventh-Century Germany, University Park.

Descatoire, Christine / Gil, Marc (eds.) (2013), Une renaissance. L'art en Flandre et Champagne 1150-1250, Paris.

Deshusses, Jean (1971), Le sacramentaire grégorien. Ses principales formes d'après les plus anciens manuscrits. I. Le sacramentaire, le supplément d'Aniane, Fribourg, 1971 (Spicilegium friburgense 16).

D’Hainaut-Zveny, Brigitte (2014), “De la diversité des manières d'exposer les reliquaires dans les sanctuaires médiévaux et de ces usages dans l'abbatiale de Stavelot (XIe-XIII siècles). De la géographie du sacré”, in: Benoît van den Bossche / Alain Dierkens / Nicolas Schroeder (eds.), À la recherche d'un temps oublié. Histoire, art et archéologie de l'abbaye de Stavelot-Malmedy au XIII' siècle. Actes du colloque organisé en mai 2012, Stavelot, 101-107.

Dumortier, Claire (ed.) (1999), La salle aux trésors. Chefs-d'œuvre de l'art roman et mosan, Turnhout.

Favreau, Robert/Michaud, Jean / Leplant, Bernadette (1984), Corpus des inscriptions de la France médiévale, 9. Aveyron, Lot, Tarn, Paris.

Fusier, Jean / Philippot, Jacques (2005), Vitraux des églises de Châlons-en-Champagne. Notre-Dameen-Vaux, Saint-Alpin, Saint-Étienne, Langres.

Gaborit-Chopin, Danielle (1991), “Le trésor du haut Moyen Âge. Dagobert et Charles le Chauve”, in: Le trésor de Saint-Denis, Paris, 41-54.

Garhammer, Erich (2000) “De la fraction du pain à l'élévation de l'hostie. L'eucharistie au Moyen -Âge”, in: Dorothee Rippmann / Brigitta Neumeister-Taroni (eds.), Les mangeurs de l'an 1000. Archéologie et alimentation, Vevey, 25-34.

George, Philippe (2013), “Sur la terre comme au ciel. L'évêque de Liège, l'abbé de Stavelot-Malmedy, le droit, la justice et l'art mosan vers 1170", in: Cahiers de civilisation médiévale, 56, 225-253. 
Gudera, Alice (2003), Der Tragaltar aus Stavelot. Ikonographie und Stil, Brême.

Henriet, Patrick (2016), “Relire l'autel portatif de Stavelot”, in: Philippe George (ed.), Orfèvrerie septentrionale (XII \& XIII siècle), Liège, 179-208.

Heriger of Lobbes, De corpore et sanguine Domini, in: Jacques-Paul Migne (ed.), Patrologia latina, vol.139.

Holbert, Kelly McKay (1995), Mosan Reliquary Triptychs and the Cult of the True Cross in the Twelfth Century, PhD, Yale University.

Honorius Augustodunensis, Gemma animae, in: Jacques-Paul Migne (éd.), Patrologia latina, vol. 172.

Hugues de Flavigny, Chronicon, Pertz (ed.), MGH SS VIII.

Jungmann, Joseph Andreas (1956-1958), Missarum sollemnia. Explication génétique de la Messe romaine, 3 vol., Paris.

Kockerols, Hadrien (2016), “Découverte d'un second dessin du retable de saint Remacle à Stavelot”, in: Philippe George (ed.), Orfèvrerie septentrionale (XII \& XIII siècle), Liège, 208-235.

Kaspersen, Søren (2006), “Narrative 'Modes' in the Danish Golden Frontals”, in: Søren Kaspersen/ Erik Thunø (eds.), Decorating the Lord's Table: On the Dynamics between Image and Altar in the Middle Ages. (International Congress on Medieval Studies, 36, 2001, Kalamazoo), Copenhagen, 79-127.

Kemper, Dorothee (2014), Die Goldschmiedearbeiten am Dreikönigenschrein. Bestand und Geschichte seiner Restaurierungen im 19. und 20. Jahrhundert, mit Beiträgen zu Materialanalysen und Herstellungstechniken, 3 vol., Cologne.

Kroos, Renate (1985), Der Schrein des heiligen Servatius in Maastricht und die vier zugehörigen Reliquiare in Brüssel, Munich.

Lambotte, (2014), "L'église abbatiale de Stavelot au XIII' siècle. Regard archéologique sur des modifications architecturales du chevet", in: Benoît van den Bossche / Alain Dierkens/Nicolas Schroeder (eds.), À la recherche d'un temps oublié. Histoire, art et archéologie de l'abbaye de Stavelot-Malmedy au XIII' siècle. Actes du colloque organisé en mai 2012, Stavelot, 47-55.

Lauer, Rolf (2006), Der Schrein der Heiligen Drei Könige, Cologne.

Lemeunier, Albert/ Didier, Robert (1988), "La châsse de saint Hadelin de Celles-Visé”, in: M.-G. Boutier/ P. Bruyère (eds.), Trésors d'art religieux aux pays de Visé et saint Hadelin, Visé, 91-198.

Lemeunier, Albert (1989), "La châsse de sainte Ode d'Amay", in: Thomas Delarue / Albert Lemeunier (eds.), Trésors de la collégiale d'Amay. Catalogue des œuvres exposées du 12 août au $24 \mathrm{sep}$ tembre 1989 en l'église Saint-Georges et Sainte-Ode d'Amay, Amay, 49-79.

Lemeunier, Albert (2010), “Autour du retable de saint Remacle de Stavelot”, in: Albert Lemeunier / Nicolas Schroeder (eds.), Wibald en questions. Un grand abbé lotharingien du XII siècle. Actes du colloque de Stavelot, 19-20 novembre 2009, Stavelot, 59-71.

Lemeunier, Albert (2012), Trésor de la collégiale Notre-Dame de Huy, Huy.

Monroe, William S. (1992), "The Guennol Triptych and the Twelfth-Century Revival of Jurisprudence", in: Mary B. Shepard / Elisabeth C. Parker (eds.), The Cloisters. Studies in Honor of the Fiftieth Anniversary, New York, 167-177.

Navez, Pierre-Louis (2005), La châsse Notre-Dame de Tournai. Un chef-d'œuvre en style 1200 du Maître-orfèvre Nicolas de Verdun - 1205, Tournai.

Reynolds, Roger E. (2013), "Eucharistic Adoration in the Carolingian Era? Exposition of Christ in the Host”, in: Peregrinations. Journal of Medieval Art and Architecture, 4/2, 70-153.

Schapiro, Meyer (1954), "Two Romanesque Drawings in Auxerre and Some Iconographic Problems”, in: Dorothy Miner (ed.), Studies in Art and Literature for Belle Da Costa Greene, Princeton, 331-349.

Schlicht, Markus / Angheben, Marcello (2016), “La sculpture gothique”, in: Jean-Claude Boulanger/ François Neveux (eds.), Bayeux, la grâce d'une cathédrale, Strasbourg, 235-248.

Seidler, Martin (2016), Der Schrein des Heiligen Heribert in Köln-Deutz, Regensburg. 
Stratford, Neil (1993), Catalogue of Medieval Enamels. Volume II: Northen Romanesque Enamel, London.

Van den Bossche, Benoît (1989-1990), "La châsse de saint Remacle à Stavelot (étude iconographique et stylistique des bas-reliefs et des statuettes”, Aachener Kunstblätter, 58, 47-73.

Van den Bossche, Benoît (2000), "Anmerkungen zu einer theologischen Betrachtungsweise des Marienschreins", in: Dieter P. J. Wynants (ed.), Der Aachener Marienschrein. Eine Festschrift, Aachen, 101-113.

Van den Bossche, Benoît (2014), "La châsse de saint Remacle, les orfèvres, l'atelier : état de la question”, in: Benoît van den Bossche/Alain Dierkens / Nicolas Schroeder (eds.), À la recherche d'un temps oublié. Histoire, art et archéologie de l'abbaye de Stavelot-Malmedy au XIII' siècle. Actes du colloque organisé en mai 2012, Stavelot, 79-85.

Van den Bossche, Benoît (2015), “Châsse de saint Éleuthère”, in: Géraldine Jaffré / Caroline Marchant (eds.), Trésors classés en Fédération Wallonie-Bruxelles, Bruxelles, 108-109.

Verdier, Philippe (1981), “The twelfth-century chasse of St. Ode from Amay”, in: Wallraf-RichartzJahrbuch, 42, 7-84.

Verdier, Philippe (1982), “Dominus potens in praelio”, in: Wallraf-Richartz-Jahrbuch, 43, 35-106. Wittekind, Susanne (2004), Altar - Reliquiar - Retabel. Kunst und Liturgie bei Wibald von Stablo, Cologne/Weimar/Vienna, 2004.

\section{Photo Credits}

Fig. 1, 5, 6, 8-11: Marcello Angheben.

Fig. 2, 3: Ph. George.

Fig. 4: Médiathèque d'Orléans.

Fig. 7: @ Hohe Domkirche Köln, Dombauhütte Köln, photo: Matz und Schenk.

Fig.12-14: KIKIRPA. 